\title{
Anthós
}

$6-21-2021$

\section{Spiders You May Encounter While Social Distancing: A Field Guide to Oregon}

Daniel K. Hufnagel

Portland State University

Follow this and additional works at: https://pdxscholar.library.pdx.edu/anthos

Part of the Behavior and Ethology Commons, Biology Commons, Entomology Commons, and the Zoology Commons

Let us know how access to this document benefits you.

\section{Recommended Citation}

Hufnagel, Daniel K. (2021) "Spiders You May Encounter While Social Distancing: A Field Guide to Oregon," Anthós: Vol. 10: Iss. 1, Article 10.

https://doi.org/10.15760/anthos.2021.10.1.10

This open access Article is distributed under the terms of the Creative Commons Attribution-NonCommercialShareAlike 4.0 International License (CC BY-NC-SA 4.0). All documents in PDXScholar should meet accessibility standards. If we can make this document more accessible to you, contact our team. 
Spiders

You May Encounter While Social Distancing:

A Field Guide to Oregon

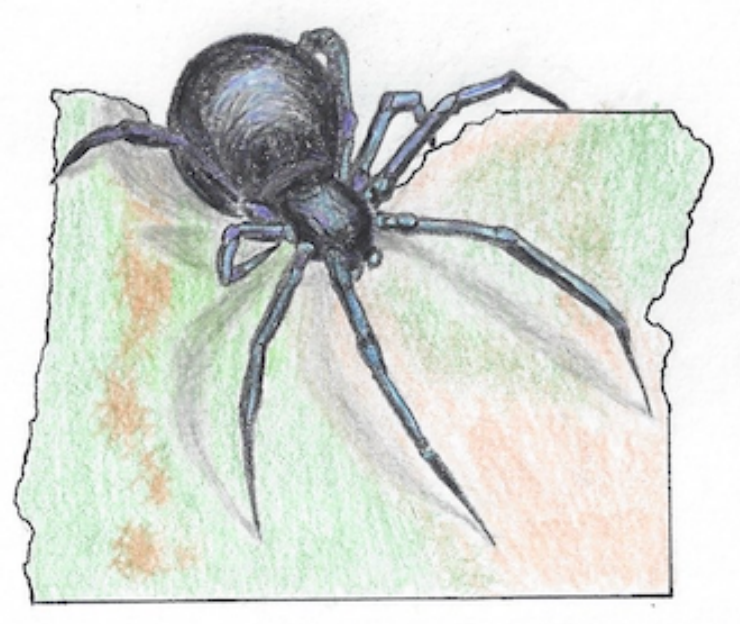


Written and Illustrated by Daniel Hufnagel 


\section{$\underline{\text { Table of Contents }}$}

Foreword.....................................................

Anatomy of a Spider.........................................2

Mouse Spider...................................................4

Long-bodied Cellar Spider...............................6

Woodlouse Hunter............................................

Cross Orb Weaver............................................10

False Black Widow........................................12

Zebra Jumping Spider...................................14 


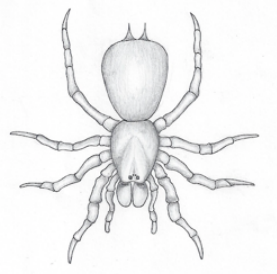

\section{Foreword}

If you've been living in Oregon for the last year, then you've likely spent the majority of your time social distancing in a cozy indoor environment, away from people and political chaos. But chances are you haven't been quarantining alone, since you may have heard that while indoors, it's impossible to be more than three feet away from spider! .. . Actually, that's only a myth, not backed by any sort of science.

That being said, you've probably seen a few spiders scurrying around your apartment here and there, or maybe occupying some forgotten corner of your bathroom. But these little critters are nothing to be afraid of. $99 \%$ of spiders in Oregon aren't considered poisonous, and $100 \%$ of spiders want absolutely nothing to do with you. The only reason spiders would ever consider getting so close to you is to snack on the other insects inhabiting your home. In fact, most of the spiders living in or around your house play key roles in keeping your residence pestfree without causing damage to property. Having spiders in your home is a lot like having a bunch of mini, environmentally friendly exterminators working in your house free of charge.

My hope is that this field guide will not only help you successfully identify the spiders living in your home but view spiders as the keystone species that they are. Our homes are our own personal niches, and each species of spider plays a vital role in keeping balance to the ecosystem that makes us feel at home. 


\section{Anatomy of a Spider}

Many of the terms used to describe the different body parts of a spider are not part of everyday vocabulary for most, so here's a diagram to help make you make sense of some of the lesser-known words in this field guide:

Abdomen: The back end of the spider that also harbors most of the major internal organs

Cephalothorax: A fusion of head and thorax that connects to the spider's legs, mouth, eyes, and other major sensory organs

Chelicerae: Mouth parts that hold the spider's fangs and venom glands

Eyes: Most spiders have eight eyes, but this number varies between species

Legs: Used for walking, jumping, and other various spider activities

Palps: Front-most appendages that are often mistaken for legs; assist the spider with touching, feeding, and mating.

Spinnerets: Small organs on the back end of the abdomen that allow spiders to make webs and silk

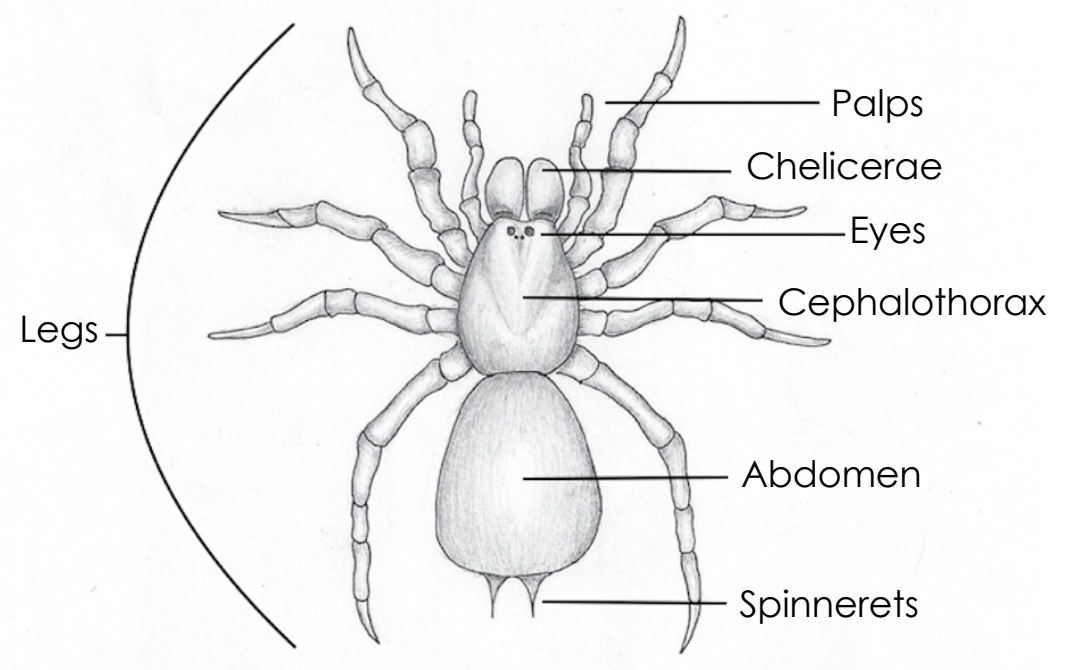




\section{Mouse Spider}

\section{Scotophaeus blackwalli}

Mouse spiders are like the house maids of domestic spiders - these speedy spiders will clean your house by feasting on any dead bugs you may have lying around your house. And during the day, mouse spiders act as live pest control for your walls and vents by removing bugs like roaches and silver fish!

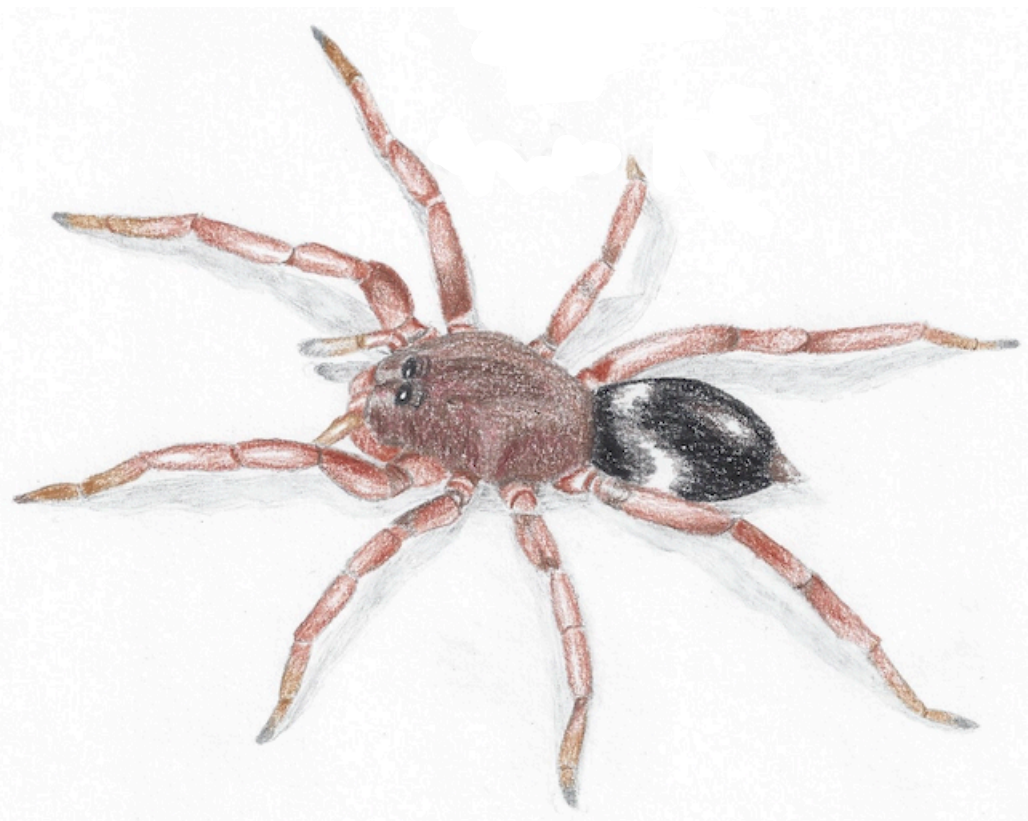

\section{Appearance}

Mouse Spiders have an abdomen that appears grayishblack and velvety - like the fur of mouse! Their cephalothorax may be a light brown or gray color. The legs of the Mouse Spider are stocky and typically the same color as the cephalothorax. Females grow to be 0.5 inches long, while males usually grow to be about 0.35 inches long.

\section{Behavior}

Mouse Spiders don't spin a web; they prefer to catch their prey on foot. Their stocky legs allow them to move like a 100-meter sprinter. They move quickly but must stop abruptly for short periods of time. When they encounter an insect, Mouse Spiders will shoot a gooey, sticky silk from their spinnerets to subdue their prey. This hunting strategy allows them take on a wide variety of prey, including other, larger spiders!

\section{Habitat}

Mouse spiders can be found virtually everywhere within your home! However, Mouse Spiders typically only hunt at night. They are often seen scurrying up your walls and ceilings. During the day, they will hide out in dark places, like in your walls and vents. 


\section{Long-bodied Cellar Spider}

\section{Pholcus phalangiodes}

The hair-thin legs of the Long-Bodied Cellar Spider may make this critter look scrawny and weak, but having one of these specimens in your room is like

having your own personal bodyguard on duty. These spiders will protect your house from venomous spiders, like the Black Widows, without invading your personal space. Their webs are also perfect for pinning down pesky flies and moths!

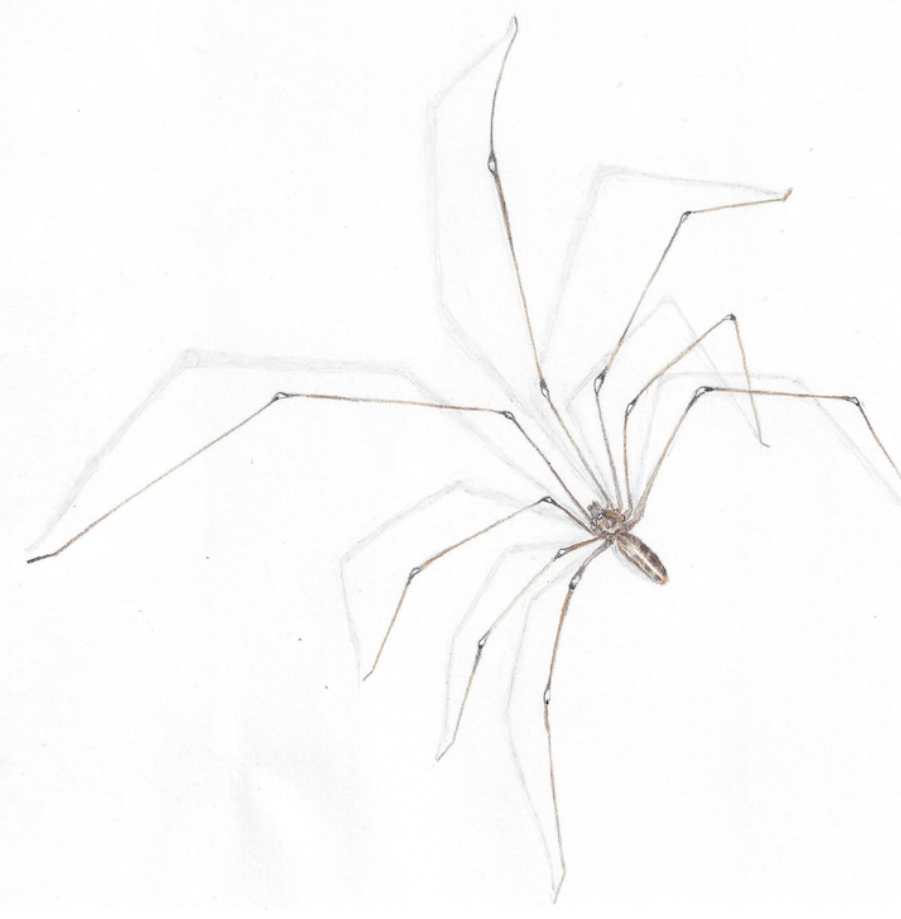

\section{Appearance}

The defining characteristic of the Long-bodied Cellar Spider is its peculiar legs. The legs of the Long-bodied Cellar Spider appear thin and delicate and can grow up to two inches in length! The legs are a pale, translucent brown color, with black and white bands at the joints. Brown splotches on the abdomen are often shaped like a skull, leading to this species commonly being called the "skull spider". Overall, the main body (cephalothorax + abdomen) is pale brown and only grows to be 0.3 inches in females and 0.25 inches in males

\section{Behavior}

Long-bodied Cellar Spiders lay upside down in their webs, waiting for other insects to woefully join them in their webs. Long Bodied Cellar Spiders are known for feeding on more venomous, domestic spiders, like the Western Black Widow and Hobo Spider, as well as members of their own species. When they feel threatened by something large, Long-bodied Cellar spiders will wobble around in their webs to make themselves harder to see. This behavior has garnered them another common name: "the vibrating spider"

\section{Habitat}

You can frequently find these spiders building their webs in the corners of heated, domestic structures. Their favorite rooms to inhabit are usually dark and quiet, which include cellars, basements, garages, and bathrooms. 


\section{Woodlouse Hunter}

Dysdera crocata

The disproportionately large fangs of the Woodlouse Hunter are intimidating to some. But don't worry, these spiders feed almost exclusively on Woodlice (aka roly-polies) and are not considered aggressive in any way. Many consider the Woodlouse Hunter to

be a natural pesticide since they control populations of woodlice while leaving homes and foliage untouched.

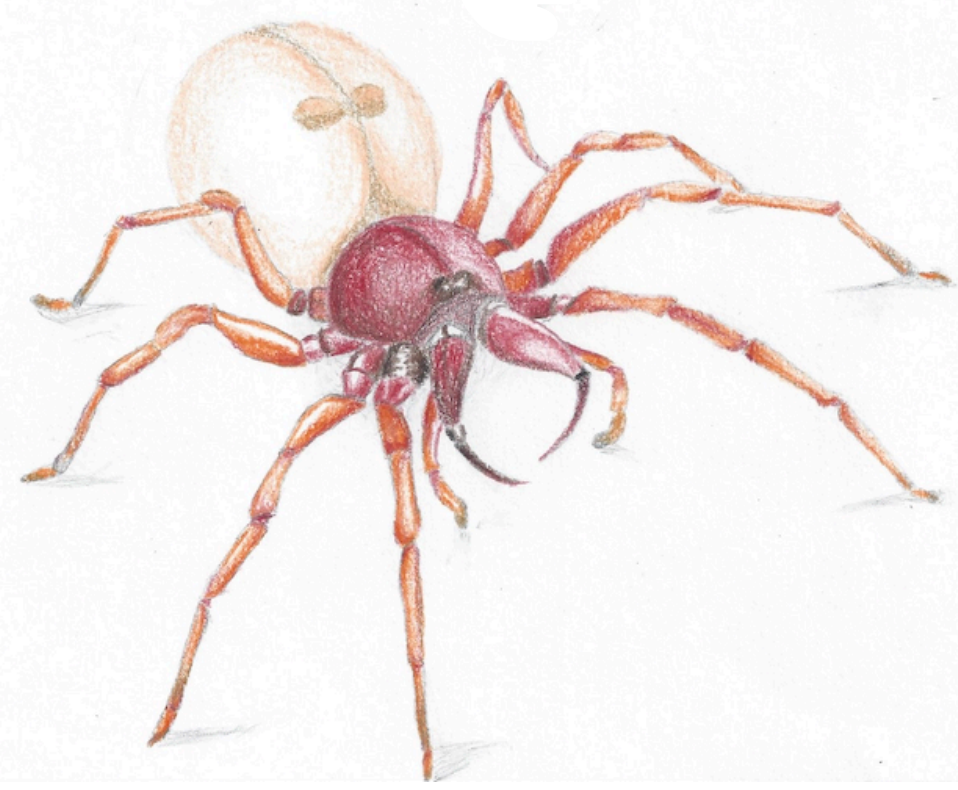

\section{Appearance}

The Woodlouse Hunter's unusual appearance makes it quite easy to spot. The cephalothorax of Woodlouse Hunters is a deep red color, while the abdomen ranges from brown to pale-gray. Their chelicerae and fangs are unusually large, which contributes to their somewhat threatening appearance. Their legs are stocky and have a flashy, bright orange coloration. Females can grow to be about 0.6 inches, while males grow to be about 0.4 inches.

\section{Behavior}

Woodlouse Hunters don't spin webs to catch their prey. During the day, these spiders reside comfortably in dark crevices reinforced with a touch of their own handmade silk. But much like the Mouse spider, Woodlouse Hunters like to catch their prey on foot. At night, they begin feasting on their favorite food: woodlice (hence the name "Woodlouse Hunter"). They use their abnormally long fangs to bypass the woodlouse's chemical defenses and penetrate their soft underbellies. Although Woodlouse Hunters mostly feed on woodlice, their large chelicerae make them a dominant predator amongst all underground invertebrates, including other spiders and even centipedes!

\section{Habitat}

You can find Woodlouse Hunters in close proximity to any population of woodlice. They are commonly found under rocks and flowerpots or inside domestic structures with rotting wood, such as backyard sheds, decks, and wooden fencing. 


\section{Cross Orb Weaver}

Araneus diademetus

Cross Orb Weavers are the ideal caretakers for any at-home garden. These critters will protect your plants from invasive herbivores like aphids and grasshoppers. Plus, their stunning webs and vivid coloration add a natural, ornamental touch to any flower garden.

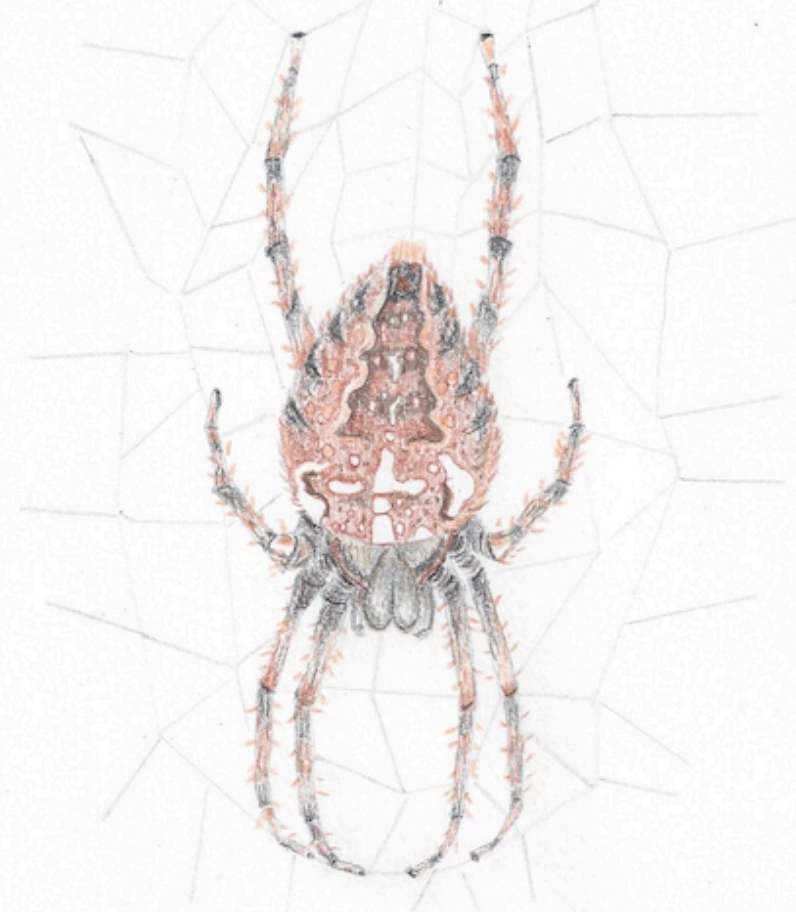

\section{Appearance}

The mosaic-like appearance of Cross Orb Weavers makes them quite a sight to see! Their abdomens are bulbous and form an amalgam of orange and brown coloration, but the abdomen's defining characteristic is the appearance of a beaded, white cross pattern. Their legs are stocky and thorny, making them a good aesthetic for any rose garden. Females can grow to be about 0.75 inches, while males tend to grow to about 0.5 inches.

\section{Behavior}

Cross Orb Weavers like to sit in the center of their large, symmetric webs, waiting to snag some prey. These spiders are rather flamboyant and like to build their intricate webs out in the open, unlike many of the spiders in this field guide. One may also consider Cross-Orb Weavers to be perfectionists, due to their need to build a new web every day! When threatened, Cross-Orb Weavers will violently shake their web to scare off any major intruders.

\section{Habitat}

You will find Cross Orb Weavers building their webs between sturdy structures with a lot of exterior light. This often includes the bushes in flower gardens, fences, windows, and outdoor recreational structures like playgrounds and basketball hoops. 


\section{False Black Widow}

\section{Steatoda grossa}

This reclusive arachnid is frequently mistaken for Oregon's only poisonous spider: The Western Black Widow. But don't be so quick to squash these little buggers! False Black Widows act as your home's hidden sentries against a wide range of intruders, including ants, roaches, other species of Black Widow.

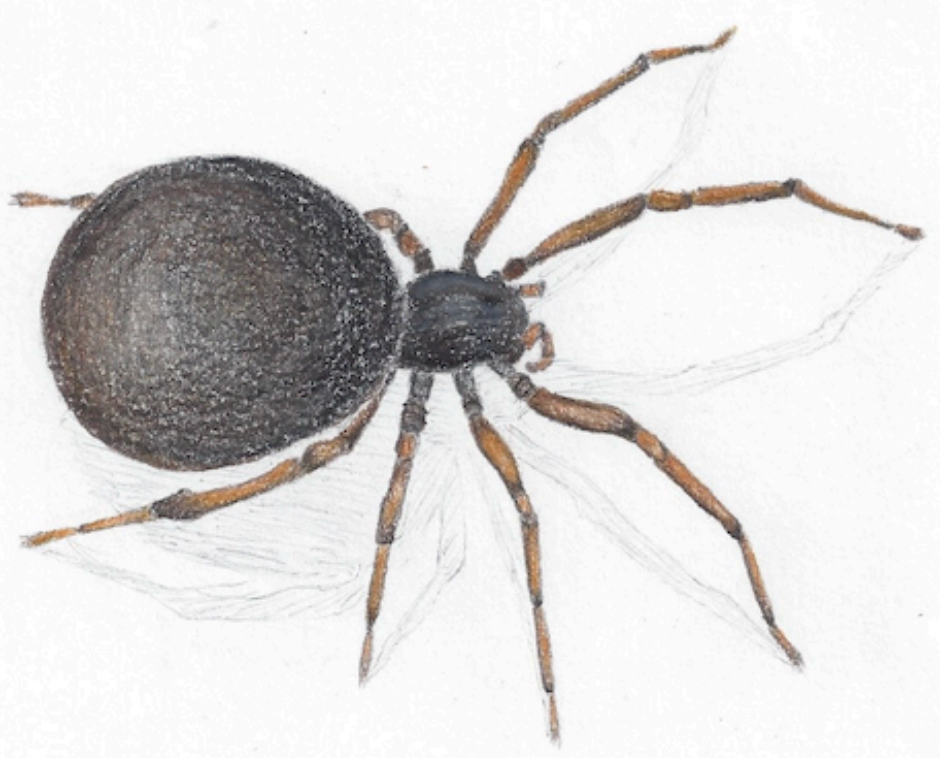

\section{Appearance}

As the name denotes, the False Black Widow has a striking resemblance to the Western Black Widow, so the defining characteristics of this spider are more apparent in what it lacks. Unlike true species of Black Widow, the False Black Widow does not have a red, violin shaped marking underneath its abdomen. And if you look closely, you'll notice the coloration of the abdomen and legs are a purplish-brown color rather than just straight black. Gray markings may be present on the abdomen, but these often fade away as the False Black Widow ages. Females tend to grow up to 0.6 inches, while males only grow up to about 0.4 inches long.

\section{Behavior}

The webs of False Black Widows are irregular and tangled, often described as being built by a drunk spider. They typically lay in or near their nest, waiting for prey to unknowingly get snagged by their messy, silken web. False Black Widows are known for eating a wide variety of crawling insects, including other species of true Black Widows. Although they are dominant amongst other small invertebrates, False Black Widows are quite cowardly amongst humans and will run away when exposed to bright light.

\section{Habitat}

You can find False Black Widow webs in any domestic structure that is compact, dark, and often quiet. This includes the nooks and crannies of sheds, garages, storage facilities, or even under furniture such as couches, stools, and tables. They also are often found in gardens underneath flowerpots, rocks, and logs. 


\section{Zebra Jumping Spider}

Salticus scenicus

Their bulbous eyes and fuzzy features make these fun-sized friends one of the cutest insect assassins to keep around your abode. Zebra Jumping Spiders use their remarkable eyesight and jumping ability to protect your residence from small, disease-carrying critters, such as mosquitos and flies.

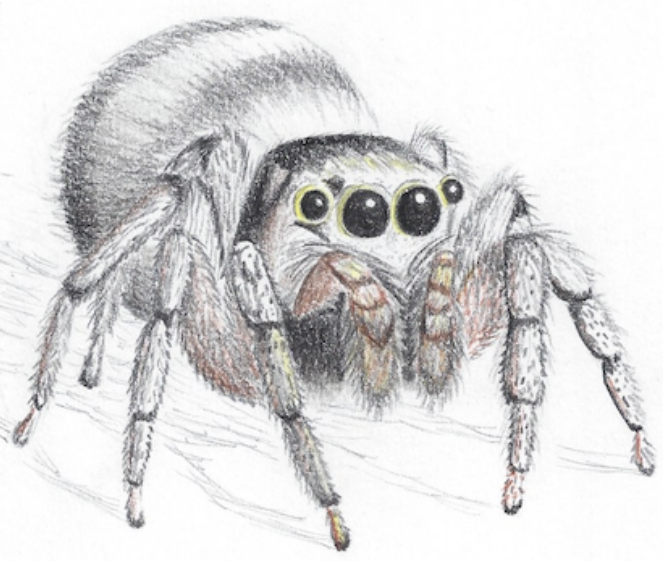

\section{Description}

Zebra Jumping are rather small relative to the other spiders in this field guide, with females reaching up to 0.25 inches and males only growing up to about 0.2 inches. Despite their compact size, these spiders have several physical qualities that make them easy to identify. Zebra Jumping Spiders have furry, black and white stripes running down their abdomen-similar to a zebra. Their fuzzy chelicerae and large, front-facing eyes gives these spiders a somewhat-adorable look, as if they are always surprised to see you. The legs of the Zebra Jumper are speckled black and also quite hairy. Their extra furry legs allow them to stick to smooth surfaces more easily.

\section{Behavior}

Zebra Jumping Spiders don't build webs to catch their prey. Instead, these little spiders choose a solitary and wandering lifestyle. During the day, Zebra Jumpers track down prey using their incredible, high-definition vision. Once they've locked-on to a target, these spiders spring forward-sometimes up to six times their own body length-to catch their prey by surprise. Zebra Jumping spiders mainly hunt down small disease vectors such as mosquitoes and flies, but they're also known for stalking ants, moths, wasps, and other spiders

\section{Habitat}

During the day, you can find Zebra Jumping Spiders in virtually any outdoor, urban environment. Often times, they are seen crawling along fences, walls, and windowpanes. You may also see them hopping around your garden between flowerpots and plants. 